\title{
A New Porphyry Mo Mineralization at Aisymi-Leptokarya, South-Eastern Rhodope, North-East Greece: Geological and Mineralogical Constraints
}

\author{
Evangelos Galanopoulos ${ }^{1}\left(\mathbb{D}\right.$, Panagiotis Voudouris ${ }^{1, *(D)}$, Constantinos Mavrogonatos ${ }^{1}(\mathbb{D}$, \\ Paul G. Spry ${ }^{2}\left(\mathbb{D}\right.$, Craig Hart ${ }^{3}$, Vasilios Melfos ${ }^{4}\left(\mathbb{D}\right.$, Federica Zaccarini ${ }^{5}$ and Dimitrios Alfieris ${ }^{6}$ \\ 1 Department of Geology and Geoenvironment, National and Kapodistrian University of Athens, \\ 15784 Athens, Greece; egalanop@geol.uoa.gr (E.G.); kmavrogon@geol.uoa.gr (C.M.) \\ 2 Department of Geological and Atmospheric Sciences, Iowa State University, Ames, IA 50011-1027, USA; \\ pgspry@iastate.edu \\ 3 Department of Earth, Ocean and Atmospheric Sciences, University of British Columbia, \\ Vancouver, BC V6T 1Z4, Canada; chart@eoas.ubc.ca \\ 4 Department of Mineralogy, Petrology, Economic Geology, Faculty of Geology, Aristotle University of \\ Thessaloniki, 54124 Thessaloniki, Greece; melfosv@geo.auth.gr \\ 5 Department of Applied Geosciences and Geophysics, University of Leoben, A-8700 Leoben, Austria; \\ federica.zaccarini@unileoben.ac.at \\ 66 Kairi str., 15126 Athens, Greece; dimitrisal@hotmail.com \\ * Correspondence: voudouris@geol.uoa.gr; Tel.: +30-210-7274129
}

Received: 8 October 2018; Accepted: 20 November 2018; Published: 24 November 2018

\begin{abstract}
A new porphyry Mo prospect has been discovered in the Aisymi-Leptokarya area, along the southern margin of the Byala Reka-Kechros metamorphic dome, south-eastern (SE) Rhodope metallogenic zone. The study area is dominated by an Oligocene felsic dike complex, which hosts the porphyry Mo mineralization and intrudes into upper Eocene sandstones-marls and the Leptokarya monzodiorite pluton. The Aisymi-Leptokarya felsic dike complex displays a rhyodacitic to dacitic composition with post-collisional affinities. The porphyry Mo mineralization occurs in the form of porphyry-style quartz stockworks in the felsic dike complex associated with potassic alteration characterized by hydrothermal K-feldspar. The ore minerals consist mainly of pyrite, molybdenite, kesterite, bismuthinite and galena within both the stockwork and the rock matrix. Bulk ore analyses indicate enrichment in Mo (up to $215 \mathrm{ppm}$ ), Se (up to $29 \mathrm{ppm}$ ), Bi (up to $8 \mathrm{ppm}$ ) and Sn (up to $14 \mathrm{ppm}$ ) in the porphyry quartz veins. Late-stage, north-east (NE-) and north-west (NW-)trending milky quartz intermediate-sulfidation epithermal veins with base metals, crosscut previous vein generations and are characterized by $\mathrm{Ag}$, Sn and Te anomalies. The Aisymi-Leptokarya porphyry Mo prospect is set in a back-arc geotectonic regime and shares similarities to other post-subduction porphyry molybdenum deposits elsewhere.
\end{abstract}

Keywords: Porphyry Mo; Thrace-Greece; Aisymi-Leptokarya

\section{Introduction}

Porphyry-type deposits are the largest source of the world's molybdenum. Currently, China, which hosts many porphyry Mo deposits is the most significant Mo producer [1]. Proven reserves are >25 Mt Mo metal (e.g., [2]) and comprise more than twice the rest world's supplies [3].

Porphyry Mo deposits have been classified into three types [4]: (1) The Endako-type (or high-fluorine), which is related to subduction environments and hosted in calc-alkaline magmatic rocks [5]. 
These deposits are characterized by fluids with low $\mathrm{CO}_{2} / \mathrm{H}_{2} \mathrm{O}, \mathrm{F} / \mathrm{Cl}$ and $\mathrm{K} / \mathrm{Na}$ ratios and a low $\mathrm{Rb}-\mathrm{Nb}$ and moderate to high $\mathrm{Sr}$ signature. They were originally described from the Endako deposit, British Columbia, Canada [5]; (2) Climax-type (or low-fluorine) is rift related. This deposit type is characterized by a high $\mathrm{F} / \mathrm{Cl}$ ratio and significant variations in their $\mathrm{CO}_{2} / \mathrm{H}_{2} \mathrm{O}$ and $\mathrm{K} / \mathrm{Na}$ ratios [6]. They also display high $\mathrm{Rb}-\mathrm{Nb}$ geochemical signatures; (3) Dabie-type was recently described by Mi et al. [7] named after the Dabie Shan orogenic belt, China and occurs in collision to post-collision environments. These deposits are genetically linked to high-K calc-alkaline to shoshonitic magmas, in syn- to post-collisional tectonic settings and are related to fluids with high $\mathrm{CO}_{2} / \mathrm{H}_{2} \mathrm{O}, \mathrm{F} / \mathrm{Cl}$ and $\mathrm{K} / \mathrm{Na}$ ratios. The class is originally represented by the giant Qian'echong Mo deposit, east China [7]. Alteration patterns in porphyry Mo deposits usually comprise an internal zone dominated by potassic alteration, which grades outwards into silicic/sericitic, propylitic and more distally to argillic assemblages [8-10].

The Thrace metallogenic province in NE Greece hosts a number of mineralization types including porphyry, high/intermediate-sulfidation, epithermal and other intrusion related systems, containing significant amounts of precious and critical metals [11-13]. Among them, many porphyry-type deposits are enriched in molybdenum, along with other commodities (e.g., $\mathrm{Cu}, \mathrm{Au}, \mathrm{Re}$ ). Characteristic examples are the Pagoni Rachi, Konos, Myli, Maronia and Melitena deposit/prospects [11-16].

A new porphyry Mo prospect was recently discovered [17] in the poorly studied Aisymi-Leptokarya area. The goal of the current contribution is to present results on the alteration, ore mineralogy and geochemistry of the porphyry Mo mineralization. We will also investigate its possible relationship to nearby mineralization and will try to establish any possible genetic links.

\section{Regional and Local Geology}

Based on previous studies [18-20], the Rhodope metamorphic core complex in the NE Thrace region, comprises two metamorphic domes, the Kesebir-Kardamos to the east and the Byala Reka-Kechros to the west (Figure 1), which are bound by extensional detachment faults [19]. The tectonostratigraphic units in these domes are from bottom to top, a basal, high-grade unit of orthogenesis with Permo-Carboniferous protoliths, an overlying high-grade metamorphic unit of continental and oceanic affinities consisting of amphibolites, marbles, schists, gneisses and metaperidotitic bodies, with protoliths which range in age from the Neoproterozoic to Early Mesozoic. The upper part of the metamorphic dome is occupied by the metasedimentary lithologies of Circum-Rhodope Belt, namely the Makri and Drymos-Melia units.

The Makri unit consists of greenschist-facies metasedimentary lithologies and is tectonically overlain by the very low-grade to un-metamorphosed Drymos-Melia rocks [21], which include the Evros ophiolite. A nummulitic limestone overlies the metasedimentary sequence [22].

An extensional tectonic regime, established in the area since Eocene times, resulted in the opening of several, E-W and N-S trending supra-detachment basins, infilled by sedimentary and volcanic lithologies [19]. These basins consist of Priabonian marly sandstones and claystones interbedded with lava flows and domes, as well as plutonic rocks [23]. The plutonic rocks display calc-alkaline to shoshonitic affinities and are located along a NE-SW direction, subparallel to the northern margins of the Aisymi-Kirki basin, thus indicating a structurally-controlled emplacement [24,25].

The Aisymi-Leptokarya area is dominated by a felsic dike complex hosting the porphyry-Mo mineralization (Figures 2 and 3), the Leptokarya pluton, a granodiorite porphyry in its southwestern part and Upper Eocene (Priabonian) volcano sedimentary rocks. 


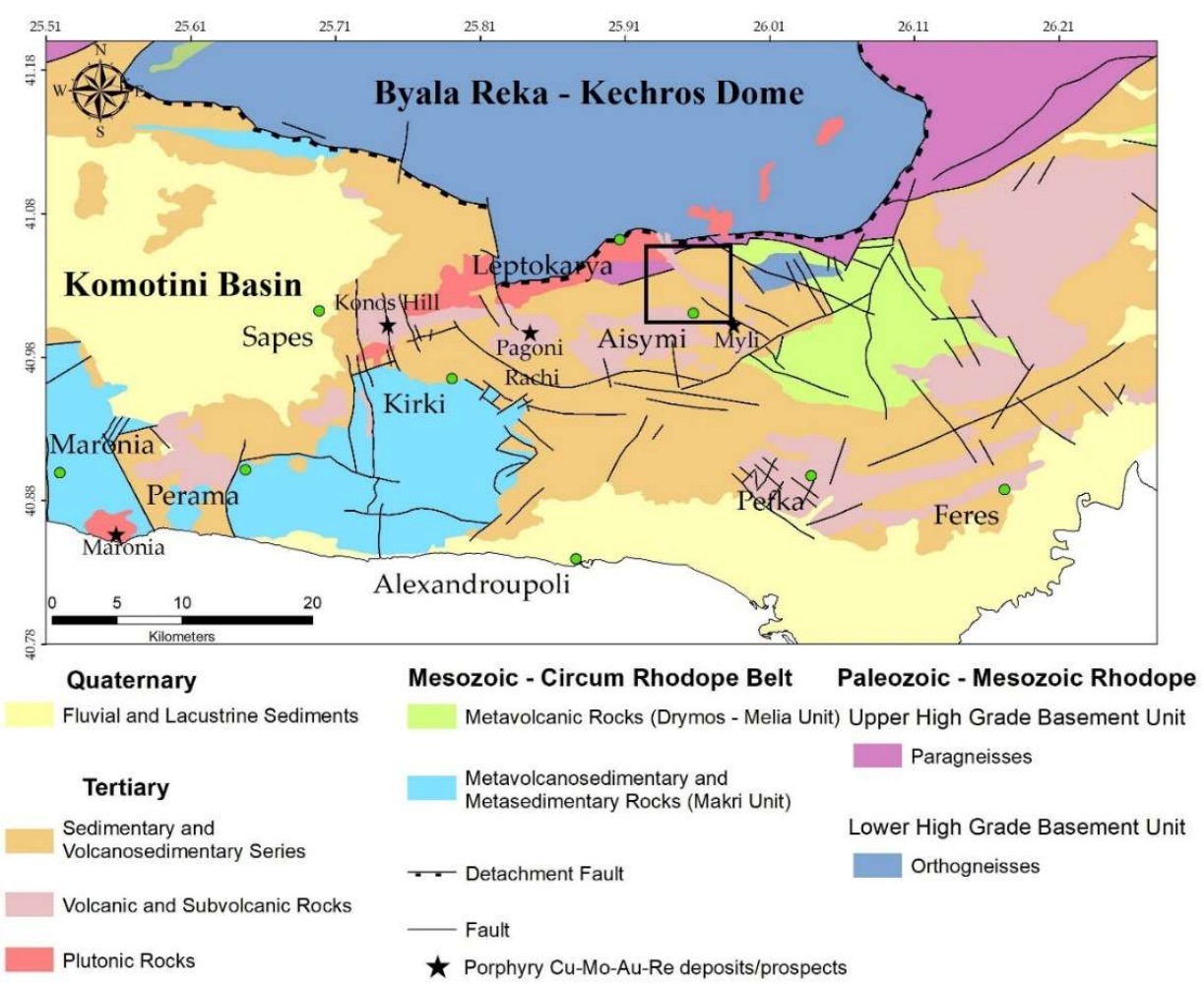

Figure 1. Simplified geological map of the south-eastern Rhodope (modified after $[11,18]$ ). Black square marks the study area.

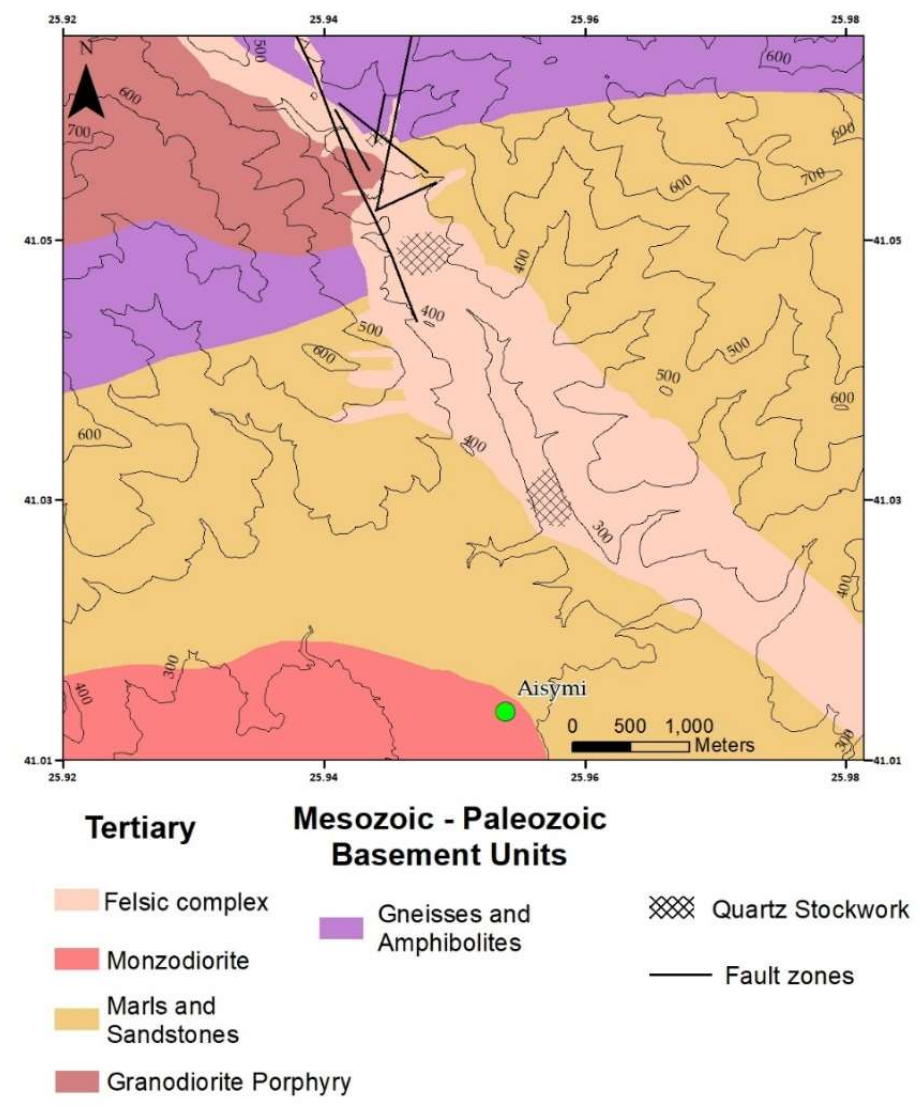

Figure 2. Geological map of the study area (this study and [11]). 

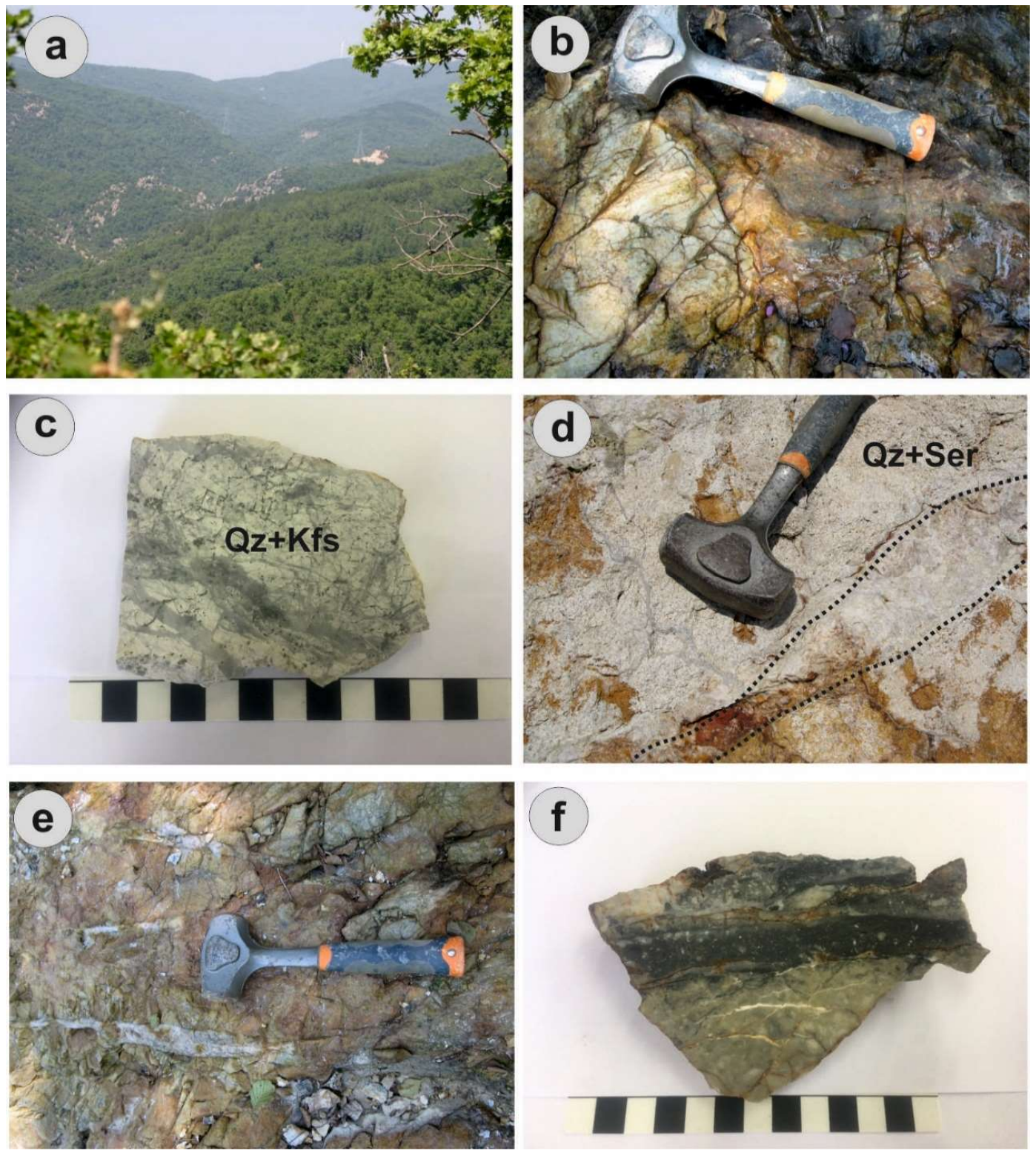

Figure 3. (a) The Aisymi-Leptokarya porphyry Mo prospect (view from $S$ to $N$ ); (b) porphyry-style quartz stockwork veins within the potassic/sodic-altered microgranite; (c) hand-specimen of quartz porphyry stockwork (A-type veins) in potassic (Kfs-K. Feldspar) altered microgranite (sample EG3); (d) D-type vein (marked by the dotted line) associated with sericitic alteration (Ser), crosscutting earlier, A-type veins (bottom left); (e) milky quartz base metal veins (E-type) crosscutting earlier formed porphyry veinlets; (f) hand-specimen of base metal vein in silicified microgranite (sample EG29).

The felsic dike complex consists of a major NW trending intrusive body, up to hundreds of meters wide and several km long, which crosscuts all the other rocks in the area (Figure 2). Alfieris et al. [26] described acid dikes (e.g., quartz \pm biotite porphyries) from the south-eastern part of the study area, with disseminated pyrite and base metal veins mineralization.

The Leptokarya pluton, forms part of a NE-trending intrusive belt that includes the Kassiteres, Kirki, Leptokarya and Tris Vrisses intrusions (Figure 1) and consists of quartz monzogabbros/monzodiorites predominantly along with tonalites and granodiorite $[24,25,27,28]$. Theses intrusive rocks are characterized by a medium-grained, granular to porphyritic texture consisting of plagioclase and variable amounts of pyroxene, amphibole, biotite and Fe-Ti oxides, with quartz and K-feldspar occurring as interstitial minerals. Radiometric data ( $\mathrm{Rb}-\mathrm{Sr}$ in biotite) yielded ages of $31.4 \pm 0.7$ to 
$31.9 \pm 0.5 \mathrm{Ma}$ [24]. Recently, Perkins et al. [28] provided a high precision age of $32.235 \pm 0.026 \mathrm{Ma}$, based on $\mathrm{Pb}-\mathrm{U}$ geochronology, for the Leptokarya pluton.

Finally, the sedimentary sequence in the area comprises marls and sandstones and is characterized by different degrees and styles of hydrothermal alteration.

\section{Materials and Methods}

A total of 33 rock and mineralized samples were collected from the Aisymi-Leptokarya prospect for petrographic, mineralogical and geochemical studies. From these rock samples, 10 thin sections, 16 polished-thin sections and 51 polished sections were made and underwent detailed mineralogical investigation using a Leica DM2500P optical microscopy mounted with a Nikon camera. All samples were pulverized using a tungsten carbide mill at $-70 \mu \mathrm{m}$ grain size and were scanned by $\mathrm{X}$-ray diffraction, using a Bruker (Siemens, Munich, Germany) D-5005 X-ray diffractometer between $3^{\circ}$ and $65^{\circ} 2 \theta$ with $1^{\circ} / \mathrm{min}$ velocity using the Ka radiation of a $\mathrm{Cu}$ X-ray tube operated at a voltage of $40 \mathrm{kV}$ and a current of $40 \mathrm{~mA}$, in conjunction with the DIFFRACplus software. Results were evaluated using EVA 10.0 software at the Department of Mineralogy and Petrology, National and Kapodistrian University of Athens. Bulk chemical analyses of 12 samples (prepared according to the PUL85 analytical protocol of ACME) were performed using an XRF (X-Ray Fluorescence) instrument using the method LF700 (2015) for major elements and LF100 (2015) for trace elements at the ACME Laboratories, Canada. Trace elements for all samples were measured using ICP-MS (Inductively Coupled Plasma Mass Spectrometry) method AQ200 (2015) by ACME, Canada. Electron Probe Micro Analyses (EPMA) analyses of sulphides and sulfosalts in ten polished sections were carried out using a Superprobe JEOL JXA 8200 electron-microprobe (Eugen F. Stumpfl laboratory, Leoben University, Leoben, Austria). The operating conditions were: accelerating voltage $20 \mathrm{kV}$, beam current $10 \mathrm{nA}$, beam size $\approx 1 \mu \mathrm{m}$. Counting times were $20 \mathrm{~s}$ on the peak and $10 \mathrm{~s}$ on the right and left backgrounds for major elements. The counting times were increased up to 60 and $30 \mathrm{~s}$ for peak and background, respectively, to analyse the trace elements. The minerals were analysed using pure metals as the reference material for $\mathrm{Ge}$, In, W and Re, synthetic $\mathrm{Bi}_{2} \mathrm{Te}_{3}, \mathrm{GaAs}, \mathrm{AgBiSe}_{2}$, cassiterite and electrum for $\mathrm{Bi}, \mathrm{Te}, \mathrm{Ga}$, Se, As, $\mathrm{Sn}$ and Ag. Natural pyrite, chalcopyrite, sphalerite, molybdenite, stibnite and galena were used for Fe, $\mathrm{Cu}, \mathrm{Zn}, \mathrm{Mo}, \mathrm{Sb}, \mathrm{Pb}$ and $\mathrm{S}$. In the following, the analytical lines and the diffracting crystals are listed for each analysed element: $\mathrm{S}=\mathrm{K} \alpha$, PETJ; $\mathrm{Ag}, \mathrm{Sb}, \mathrm{Mo}=\mathrm{L} \alpha$, PETJ; Bi, $\mathrm{Re}=\mathrm{M} \alpha, \mathrm{PETJ} ; \mathrm{Fe}, \mathrm{Cu}, \mathrm{Zn}=\mathrm{K} \alpha$, LIFH; As, Se, Ge = L $\alpha$, TAP; Te, In, $\mathrm{Sn}=\mathrm{L} \alpha, \mathrm{PETH} ; \mathrm{Pb}=\mathrm{M} \alpha$ PETH; $\mathrm{W}=\mathrm{L} \alpha, \mathrm{LIF} ; \mathrm{Ga}=\mathrm{K} \alpha$, LIF.

All maps were made using ArcGIS 10.4 by ESRI.

\section{Results and Discussion}

\subsection{Petrology and Geochemistry of the Aisymi-Leptokarya Magmatic Rocks}

The Aisymi-Leptokarya felsic dike complex is texturally inhomogeneous and consists of at least two variants, both of which are hydrothermally altered: (a) a strongly silicified and sericitized equigranular to porphyritic variety, dominated by subhedral to anhedral quartz, K-feldspar (replaced by kaolinite) and sericite (pseudomorph after primary biotite) (Figure 4a). Spherulitic aggregates of quartz and K-feldspar are commonly present (Figure 4a), together with graphic textures of quartz and orthoclase; (b) a porphyritic variety, which includes quartz and K-feldspar phenocrysts embedded within a microcrystalline matrix of quartz and possible feldspars (Figure $4 \mathrm{~b}$ ). This variety resembles the acid dike rocks described by Alfieris et al. [26] and mostly occurs along the south-eastern margin of the Aisymi-Leptokarya felsic dike complex.

The Leptokarya pluton is a medium-grained, equigranular to porphyritic quartz monzodiorite, that contains plagioclase and variable amounts of pyroxene, amphibole, biotite and Fe-Ti oxides. Quartz and K-feldspar occur as interstitial minerals. In places, the monzodiorite is characterized by different styles of hydrothermal alteration (e.g., potassic alteration, Figure 4c). 

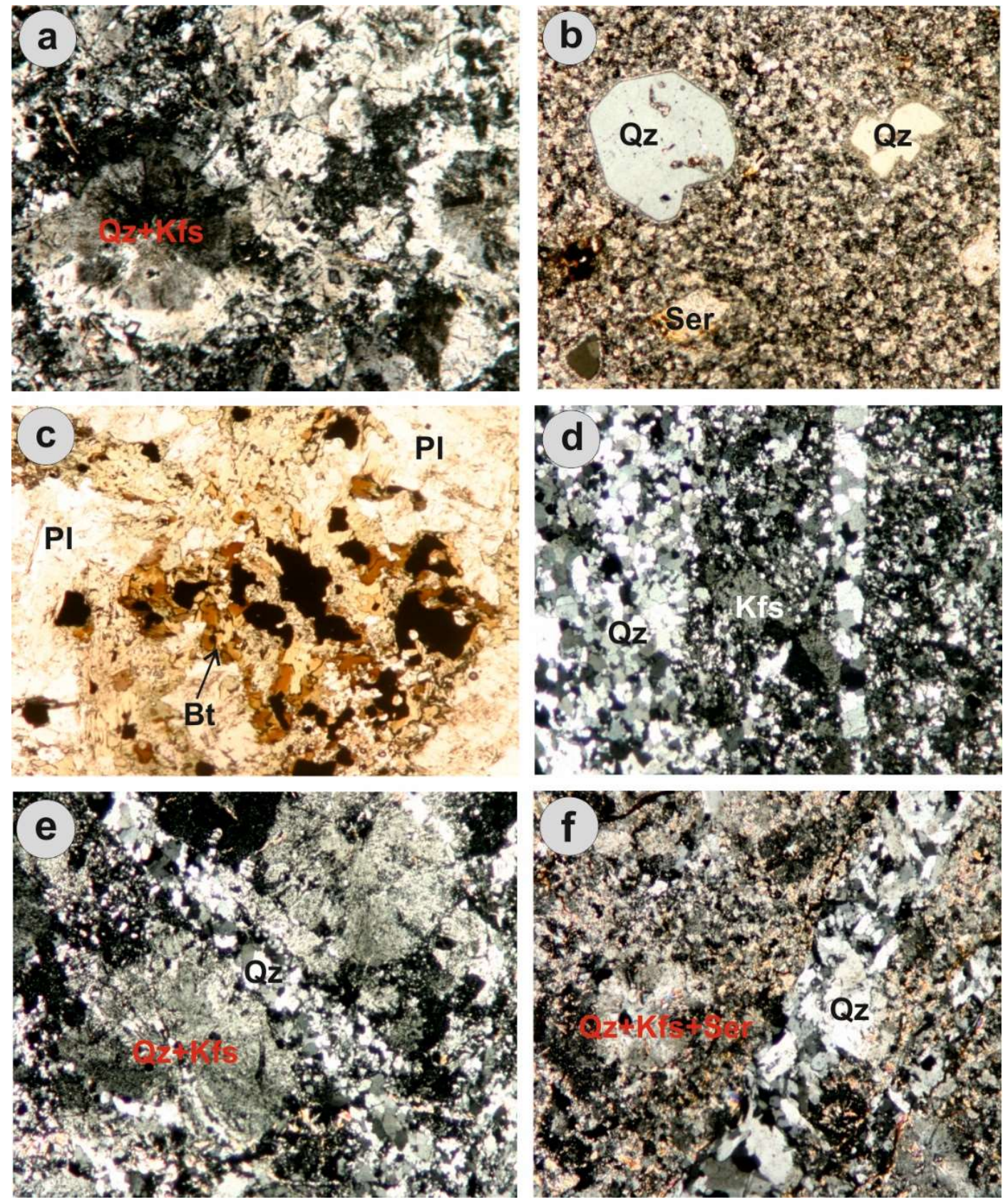

Figure 4. Microphotographs showing host rock lithologies and hydrothermal alteration at Aisymi-Leptokarya prospect. (a) Spherulitic quartz (Qz)-K-feldspar (Kfs) intergrowth in equigranular to porphyritic microgranite (crossed nicols, sample EG8); (b) Porphyritic microgranite composed of magmatic quartz (Qz) and sericitic (Ser) altered K-feldspar (Kfs) phenocrysts embedded in a quartz-sericite matrix (crossed nicols, sample EG21); (c) Selective potassic-sodic alteration of monzodiorite including hydrothermal biotite $(\mathrm{Bt})$ and pyrite (black). $\mathrm{Pl}$ = plagioclase (plain polarized light, sample EG28); (d) porphyry-style quartz veinlets (Qz) related to potassic (Kfs) alteration (crossed nicols, sample EG6); (e,f) quartz (Qz)-K-feldspar (Kfs) spherulites crosscut by porphyry-style stockworks. Late sericite (Ser) is also present (crossed nicols, samples EG16 and EG15). Host rock in microphotographs $(\mathbf{d})$ to $(\mathbf{f})$ is microgranite. Length of the microphotographs $=2.6 \mathrm{~mm}$.

Chemical compositions of the Aisymi-Leptokarya magmatic rocks are summarized in Table 1. Due to strong hydrothermal alteration, discrimination diagrams for granitoids are not suitable for the studied samples. Using the immobile element $\mathrm{Zr} / \mathrm{TiO}_{2}$ versus $\mathrm{Nb} / \mathrm{Y}$ diagram [29] the felsic dike samples show a rhyodacitic to dacitic composition (in accordance with previous studies 
by Alfieris et al. [26]), with some samples plotting in the trachyandesitic field, possibly due to hydrothermal alteration (Figure 5a). Accordingly, these rocks can be regarded as microgranite porphyries. In the $\mathrm{Zr} / \mathrm{TiO}_{2}$ versus $\mathrm{Nb} / \mathrm{Y}$ diagram samples from the Leptokarya pluton plot in or near the andesite field. Accordingly, the Leptokarya pluton is a monzodiorite. In the Rb versus $\mathrm{Y}+\mathrm{Nb}$ diagram $[30,31]$, the magmatic rocks are mostly characterized by post-collisional affinities (Figure 5b). Compositional variations in the felsic dike samples, could be attributed to hydrothermal alteration, which could result in erroneously low values of $\mathrm{Rb}$ for these rocks.

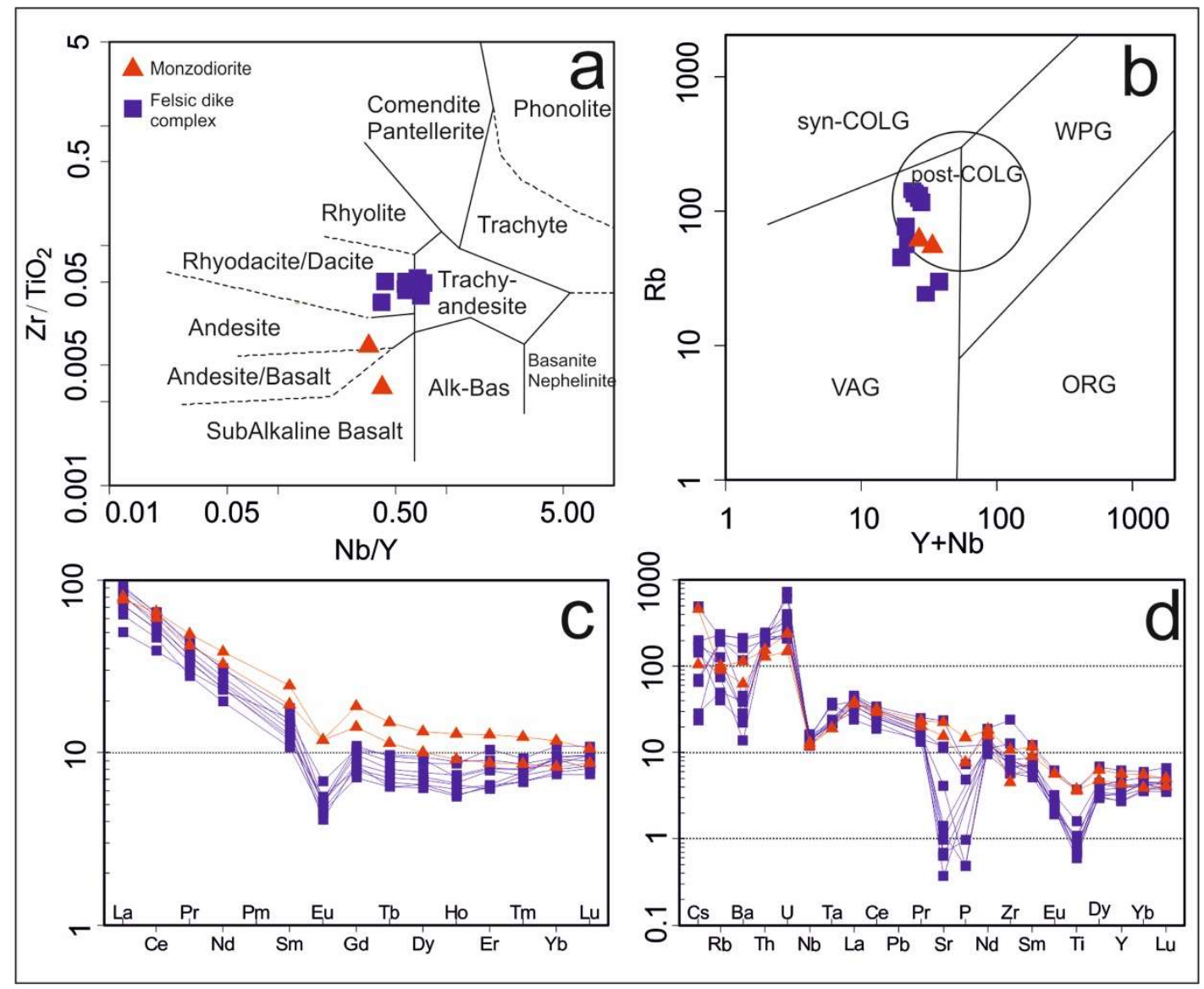

Figure 5. (a) Classification of the studied magmatic rocks based on the $\mathrm{Zr} / \mathrm{TiO}_{2}$ versus $\mathrm{Nb} / \mathrm{Y}$ diagram after Winchester and Floyd [29]; (b) Rb versus $\mathrm{Y}+\mathrm{Nb}$ diagram after Pearce and Harris [30]. VAG, Volcano Arc Granite; Syn-COLG, Syn-collision Granite; WPG, Within-Plate Granite; ORG, Ocean Ridge Granite, post-COLG, Post-collision Granite. The field of post-collisional granite (Post-COLG) is from Pearce [31]; (c) chondrite-normalized rare earth elements after Boynton [32] and (d) primitive mantle trace elements- normalized patterns of the studied rocks after McDonough and Sun [33].

The microgranite porphyry and the Leptokarya monzodiorite display different chondrite-normalized rare earth element (REE) (Figure 5c) and mantle-normalized trace element patterns (Figure 5d). The microgranite samples have subparallel chondrite-normalized REE patterns and show strong light REE enrichment $(\mathrm{La} / \mathrm{Sm}=3.14-6.37)$ but almost unfractionated heavy REEs $(\mathrm{Tb} / \mathrm{Y}=0.74-1.12)$. They also display a negative Eu anomaly $(\mathrm{Eu} / \sqrt{ }(\mathrm{Sm}+\mathrm{Gd})=0.37-0.58)$. The Eu anomalies are chiefly controlled by feldspars, particularly in felsic magmas, thus the removal of feldspar from felsic melt by crystal fractionation or partial melting of the rock will give rise to a negative Eu anomaly. The monzodiorite samples have subparallel patterns with the microgranite porphyry but are more enriched in all REEs.

In Figure $5 d$, the samples of microgranite display enrichment of LILE relative to HSFE, negative anomalies of $\mathrm{Nb}, \mathrm{Ta}, \mathrm{P}, \mathrm{Ti}$ and positive anomalies of $\mathrm{K}, \mathrm{Zr}$ and $\mathrm{Pb}$, typical for convergent boundaries 
magmatism, which is consistent with the findings in previous studies for igneous rocks in the Evros area by Christofides et al. [34]. Compositional variations in the microgranite samples within for same element, can be attributed to different degrees of hydrothermal alteration (e.g., $\mathrm{Ba}, \mathrm{Rb}$ ). The monzodiorite, displays quite the opposite geochemical features, as it appears enriched in HSFE and relatively depleted in LILE, always compared to the microgranite samples.

Table 1. Chemical composition of rock samples from the Aisymi-Leptokarya prospect. Values are in wt.\% for major elements (acquired by XRF) and in ppm for trace elements (acquired by ICP-MS).

\begin{tabular}{|c|c|c|c|c|c|c|c|c|c|c|c|}
\hline \multirow{2}{*}{$\begin{array}{c}\text { Rock Type } \\
\text { Sample }\end{array}$} & \multicolumn{9}{|c|}{ Microgranite Porphyry } & \multicolumn{2}{|c|}{ Monzodiorite } \\
\hline & EG8 & EG10 & EG13 & EG15 & EG19 & EG20 & EG22 & EG23 & EG32 & EG9 & EG28 \\
\hline $\mathrm{SiO}_{2}$ & 78.6 & 83 & 79.2 & 80.6 & 80.5 & 82.8 & 76.3 & 72.5 & 82.9 & 58.2 & 55.8 \\
\hline $\mathrm{TiO}_{2}$ & 0.14 & 0.13 & 0.17 & 0.14 & 0.18 & 0.14 & 0.22 & 0.31 & 0.11 & 0.69 & 0.73 \\
\hline $\mathrm{Al}_{2} \mathrm{O}_{3}$ & 12.3 & 11.3 & 13.6 & 12.1 & 12.3 & 11.2 & 12.8 & 14.2 & 10.1 & 14.5 & 13.4 \\
\hline $\mathrm{Fe}_{2} \mathrm{O}_{3}$ & 0.27 & 0.18 & 0.15 & 0.23 & 0.35 & 0.24 & 0.33 & 1.11 & 1.16 & 5.71 & 8.62 \\
\hline $\mathrm{MnO}$ & bdl & $\mathrm{bd}$ & $\mathrm{bd}$ & $\mathrm{bd}$ & $\mathrm{bd}$ & $\mathrm{bd}$ & 0.01 & 0.02 & 0.06 & 0.22 & 0.59 \\
\hline $\mathrm{MgO}$ & 0.12 & 0.14 & 0.19 & 0.3 & 0.15 & 0.05 & 0.38 & 0.95 & 0.21 & 5.06 & 6.09 \\
\hline $\mathrm{CaO}$ & 0.03 & 0.02 & 0.03 & 0.02 & 0.03 & 0.03 & 0.46 & 0.84 & 0.07 & 6.44 & 7.17 \\
\hline $\mathrm{Na}_{2} \mathrm{O}$ & 0.12 & $\mathrm{bd}$ & 0.12 & 0.05 & 0.25 & 0.02 & 2.37 & 3.33 & bd & 2.88 & 2.3 \\
\hline $\mathrm{K}_{2} \mathrm{O}$ & 5.19 & 0.81 & 1.54 & 2.87 & 3.43 & 0.51 & 4.93 & 4.68 & 0.99 & 2.32 & 1.32 \\
\hline $\mathrm{P}_{2} \mathrm{O} 5$ & 0.01 & $\mathrm{bd}$ & $\mathrm{bd}$ & $\mathrm{bd}$ & 0.02 & 0.01 & $\mathrm{bd}$ & 0.1 & $\mathrm{bd}$ & 0.15 & 0.3 \\
\hline LOI & 2.48 & 3.82 & 4.1 & 2.61 & 1.76 & 4.16 & 1.31 & 1.34 & 3.74 & 2.83 & 3.24 \\
\hline Total & 99.51 & 99.43 & 99.14 & 99.06 & 99.03 & 99.19 & 99.26 & 99.56 & 99.4 & 99.55 & 99.7 \\
\hline $\mathrm{Ba}$ & 1351 & 91 & 187 & 299 & 776 & 146 & 1410 & 1067 & 188 & 750 & 417 \\
\hline Co & 0.4 & 0.6 & 0.3 & $\mathrm{bd}$ & 0.3 & 0.7 & 0.5 & 1.5 & 1.8 & 19 & 23.6 \\
\hline Cs & 4.1 & 3 & 3.6 & 10.3 & 1.5 & 3.4 & 0.5 & 1.4 & 4.2 & 2.2 & 9.6 \\
\hline $\mathrm{Ga}$ & 9.9 & 9.6 & 10.1 & 10.2 & 12.7 & 6.8 & 10.1 & 12.9 & 6 & 14.1 & 15.6 \\
\hline $\mathrm{Hf}$ & 2.8 & 2.2 & 2.8 & 2.9 & 3 & 2.5 & 3 & 3.6 & 2.1 & 1.7 & 2.9 \\
\hline $\mathrm{Nb}$ & 9.6 & 8 & 8.9 & 9.7 & 9.3 & 8.9 & 10.3 & 9.9 & 7.9 & 7.8 & 8.5 \\
\hline $\mathrm{Rb}$ & 141 & 44.8 & 76.1 & 130 & 123 & 24 & 134 & 116 & 56.6 & 60.7 & 54 \\
\hline Sn & 2 & 4 & 4 & 6 & 34 & 2 & 2 & 3 & 2 & 6 & 7 \\
\hline $\mathrm{Sr}$ & 81.5 & 12.7 & 28.3 & 7.4 & 13.7 & 23.1 & 227 & 235 & 19.5 & 309 & 445 \\
\hline $\mathrm{Ta}$ & 0.8 & 0.8 & 0.8 & 0.9 & 0.8 & 0.9 & 1.3 & 1.4 & 0.8 & 0.7 & 0.7 \\
\hline Th & 18.5 & 16.1 & 16 & 18.1 & 18 & 19 & 19.5 & 15.7 & 15 & 12.5 & 10.4 \\
\hline $\mathrm{U}$ & 8.1 & 4.2 & 4.8 & 5.6 & 4.3 & 12.2 & 6.8 & 7.3 & 14.7 & 4.8 & 3 \\
\hline $\mathrm{V}$ & 14 & 14 & 10 & 11 & 9 & 19 & 9 & 43 & 11 & 177 & 220 \\
\hline $\mathrm{W}$ & 1.7 & 2.9 & 1.9 & 4.9 & 6.1 & 2.3 & 0.5 & 0.9 & 1.8 & 2.8 & 0.9 \\
\hline $\mathrm{Zr}$ & 76.3 & 60.7 & 85.9 & 70 & 87 & 74.7 & 85.6 & 134 & 60.3 & 48 & 112.7 \\
\hline $\mathrm{Y}$ & 14.2 & 11.7 & 12 & 16.9 & 16.8 & 20.4 & 14.3 & 17.6 & 13.6 & 18.7 & 24.5 \\
\hline $\mathrm{La}$ & 22.3 & 19.6 & 25.3 & 28.8 & 28.1 & 27.1 & 25.6 & 15.5 & 22.3 & 24.9 & 24 \\
\hline $\mathrm{Ce}$ & 41.8 & 37.5 & 46.7 & 52.2 & 52.7 & 49.9 & 44.7 & 31.6 & 42.5 & 49 & 53.1 \\
\hline $\operatorname{Pr}$ & 4.08 & 3.41 & 4.44 & 5.22 & 5.3 & 4.82 & 4.47 & 3.64 & 4.18 & 5.13 & 5.96 \\
\hline $\mathrm{Nd}$ & 14.3 & 11.9 & 15.1 & 18.6 & 18.2 & 16.5 & 15.5 & 13.9 & 14.1 & 19.7 & 23.1 \\
\hline $\mathrm{Sm}$ & 2.3 & 2.1 & 2.48 & 2.97 & 3.52 & 2.83 & 2.66 & 3.08 & 2.4 & 3.72 & 4.77 \\
\hline $\mathrm{Eu}$ & 0.41 & 0.33 & 0.38 & 0.37 & 0.39 & 0.37 & 0.3 & 0.5 & 0.34 & 0.87 & 0.87 \\
\hline $\mathrm{Gd}$ & 2.05 & 1.86 & 2.21 & 2.53 & 2.83 & 2.68 & 2.24 & 2.72 & 2.07 & 3.66 & 4.81 \\
\hline $\mathrm{Tb}$ & 0.32 & 0.3 & 0.3 & 0.38 & 0.45 & 0.42 & 0.36 & 0.46 & 0.34 & 0.54 & 0.71 \\
\hline Dy & 2.1 & 2.11 & 2.01 & 2.47 & 2.95 & 2.81 & 2.32 & 3.04 & 2.24 & 3.23 & 4.25 \\
\hline Ho & 0.44 & 0.41 & 0.4 & 0.53 & 0.52 & 0.62 & 0.48 & 0.64 & 0.47 & 0.66 & 0.92 \\
\hline Er & 1.37 & 1.32 & 1.35 & 1.71 & 1.68 & 2.19 & 1.65 & 1.9 & 1.29 & 1.82 & 2.68 \\
\hline $\mathrm{Tm}$ & 0.25 & 0.22 & 0.22 & 0.26 & 0.26 & 0.3 & 0.24 & 0.28 & 0.24 & 0.28 & 0.4 \\
\hline $\mathrm{Yb}$ & 1.92 & 1.56 & 1.61 & 1.91 & 1.79 & 2.28 & 2 & 1.96 & 1.67 & 1.73 & 2.45 \\
\hline $\mathrm{Lu}$ & 0.26 & 0.24 & 0.26 & 0.29 & 0.31 & 0.35 & 0.31 & 0.31 & 0.27 & 0.28 & 0.34 \\
\hline Mo & 1 & 56.9 & 2.3 & 4.2 & 20.9 & 0.9 & $\mathrm{bd}$ & 0.1 & 2.9 & 1.1 & 1.1 \\
\hline $\mathrm{Cu}$ & 8.2 & 12.2 & 15.5 & 2.6 & 5.8 & 2.7 & 3.7 & 3.9 & 4.5 & 89.1 & 2.9 \\
\hline $\mathrm{Pb}$ & 32.9 & 13.1 & 97.1 & 9.9 & 7.9 & 11.7 & 2.7 & 5.3 & 20.7 & 12.3 & 4.4 \\
\hline $\mathrm{Zn}$ & 249 & 6 & 6 & 4 & 4 & 3 & 17 & 402 & 72 & 120 & 157 \\
\hline $\mathrm{Ni}$ & 0.7 & 2.8 & 1.5 & 0.2 & 0.1 & 0.8 & 0.4 & 13.2 & 3.1 & 42.6 & 73.5 \\
\hline As & 2 & 4.4 & 1.8 & 0.8 & 1.1 & 1.2 & $\mathrm{bd}$ & $\mathrm{bd}$ & 1 & 2.9 & 0.6 \\
\hline $\mathrm{Cd}$ & 1.6 & bd & $\mathrm{bd}$ & $\mathrm{bd}$ & $\mathrm{bd}$ & $\mathrm{bd}$ & 0.1 & 0.5 & 0.4 & 0.5 & $\mathrm{bd}$ \\
\hline Sc & 0.5 & 0.4 & 0.6 & 0.3 & 0.3 & 0.5 & 0.6 & 1.9 & 0.6 & 4.3 & 3.7 \\
\hline
\end{tabular}

bdl: below detection limit.

\subsection{Mineralization and Alteration}

Mineralization comprises: (a) porphyry-type quartz stockworks (A- and D-type veins according to Seedorf et al. [35] in the microgranite porphyry and partly in the monzodiorite; (b) sulphide disseminations hosted in both magmatic rocks; and (c) base metal veins (E-type veins), which crosscut the previous styles of mineralization. 
The A-type veins in the core of the system are associated with potassic (hydrothermal K-feldspar) alteration (Figure 3b,c and Figure 4d,e; Table 2). In places, D-type veins are associated with phyllic alteration (Figure 4b,f; Table 2) and overprint earlier style of mineralization and alteration. Localized potassic-sodic alteration characterized by hydrothermal biotite and albite (Figure 4c) is also present within the Leptokarya monzodiorite.

Porphyry-style mineralization consists mainly of pyrite, molybdenite, magnetite, kesterite, bismuthinite and galena within the A-type veins and as disseminations in the rock matrix. Pyrite is present in anhedral crystals in all samples, whereas molybdenite occurs as isolated flakes in both the quartz veins and the microgranite (Figure $6 \mathrm{a})$. Kesterite, $\left(\mathrm{Cu}_{2}(\mathrm{Zn}, \mathrm{Fe}) \mathrm{SnS}_{4}\right)$, a relatively rare member of the stannite group, is also present in porphyry-style veins. It is included in pyrite either as isolated grains, or associated with bismuthinite (Figure $6 b, c$ ). Bismuthinite forms small blebs in pyrite (Figure 6d). D-type veins host pyrite mineralization associated with sericitic alteration in both the microgranite and the monzodiorite. In the elevated part of the prospect, oxidation of ore minerals, most probably argentiferous galena, resulted in the formation of supergene acanthite (Figure 6e).
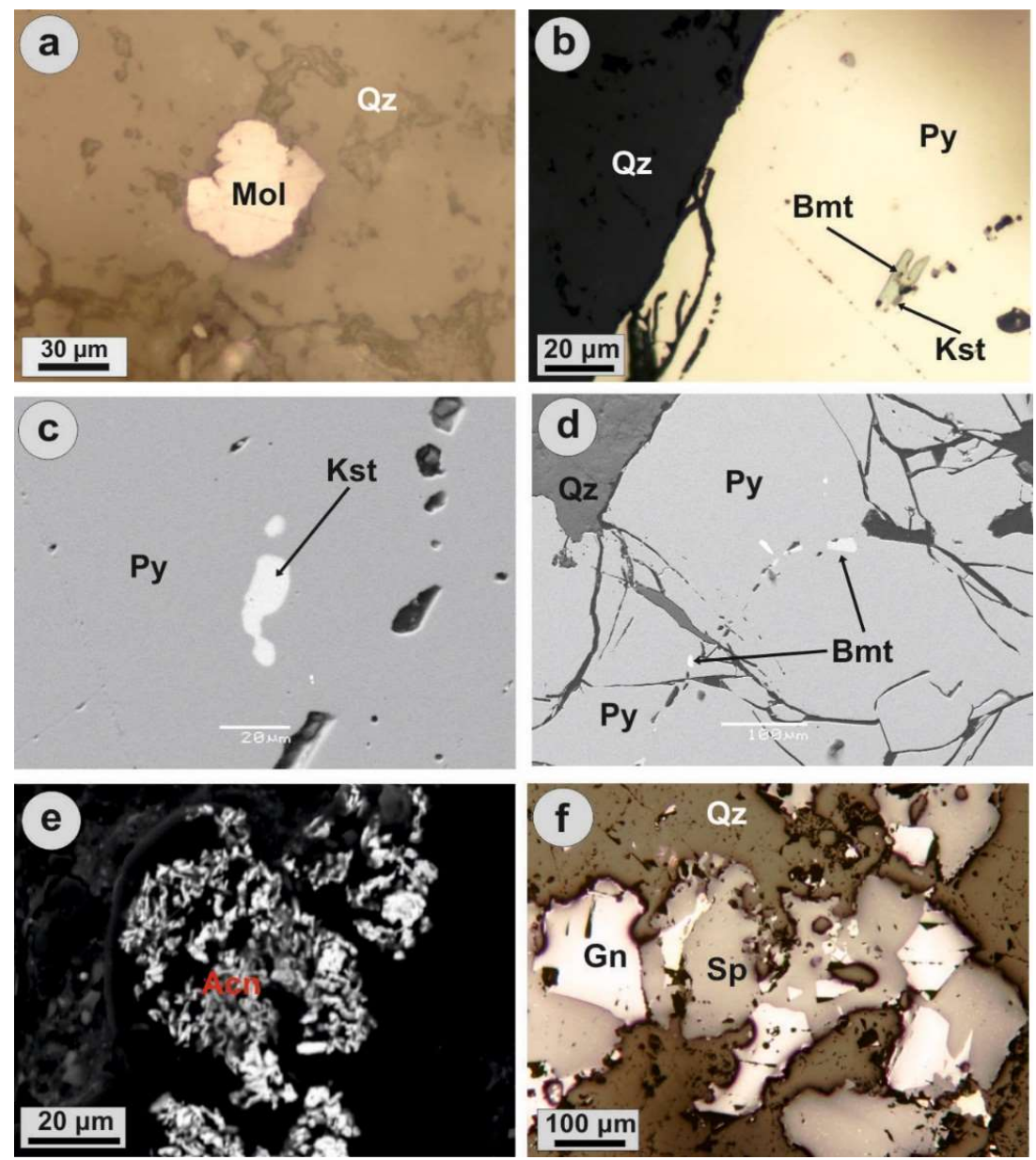

Figure 6. Reflected light microphotographs (plain polarized light, $\mathbf{a}, \mathbf{b}, \mathbf{f}$ ) and back-scattered electron images $(\mathbf{c}, \mathbf{d}, \mathbf{e})$ of the metallic minerals assemblages from the Aisymi-Leptokarya prospect. (a) Molybdenite (Mol) included in quartz (Qz) (Sample EG10, potassic-altered microgranite porphyry); (b) Kesterite (Kst) and bismuthinite (Bmt) included in pyrite (Py) Sample EG3, potassic-altered microgranite porphyry; (c) Kesterite (Kst) and (d) bismuthinite (Bmt) included in pyrite (Py) (Sample EG3, potassic-altered microgranite porphyry); (e) Skeletal acanthite (Sample EG25; oxidized/phyllic-altered microgranite porphyry); (f) Galena (Gn) in association with sphalerite (Sp) (Sample EG1, base metal vein). 
Late-stage, NE- and NW-trending, epithermal-style (E-type), milky quartz veins with base metal sulphides crosscut all earlier-formed vein generations and are associated with sericite-rich alteration assemblages (Figure 3e,f). Mineralization is composed of early pyrite followed by sphalerite and then by galena (Figure 31). Fahlores (zincian tennantite) and minor chalcopyrite are also present.

Table 2. Mineralogical content of selected hydrothermally-altered samples defined by X-ray diffraction (XRD) analyses.

\begin{tabular}{|c|c|c|c|c|c|c|c|c|c|}
\hline Sample & Lithology & Alteration & $\mathrm{Qz}$ & K-fs & Pl & $\mathrm{Hbl}$ & Bt & Chl & Ser \\
\hline EG06 & \multirow{5}{*}{ Microgranite porphyry } & potassic & + & + & & & & & \\
\hline EG08 & & potassic & + & + & & & & & \\
\hline EG15 & & potassic/phyllic & + & + & & & & & + \\
\hline EG16 & & potassic/phyllic & + & + & & & & & + \\
\hline EG21 & & potassic/phyllic & + & & & & & & + \\
\hline EG9 & \multirow{2}{*}{ Monzodiorite } & propylitic & + & + & + & + & + & + & \\
\hline EG28 & & potassic/sodic & + & & + & & + & & \\
\hline
\end{tabular}

Abbreviations: Qz = quartz; K-fs = K-feldspar; $\mathrm{Pl}=$ plagioclase; $\mathrm{Hbl}=$ hornblende; $\mathrm{Bt}=$ biotite; $\mathrm{Chl}=$ chlorite; Ser $=$ sericite.

\subsection{Mineral Chemistry}

Molybdenite is characterized by varying rhenium concentration from below detection to $0.3 \mathrm{wt} . \%$. Electron-microprobe data of molybdenite compositions are presented in Table 3 and all data are plotted in a binary Re versus Mo diagram (Figure 7). Minor amounts of Sn and W were also identified (up to 0.08 and $0.02 \mathrm{wt} . \%$ respectively). Finally, traces of Se (up to $0.04 \mathrm{wt} . \%$ ) substitute $\mathrm{S}$ in the structure of the molybdenite.

Kesterite revealed almost stoichiometric composition, with a minor substitution of Sn by In (values up to $0.70 \mathrm{wt} . \%$ ) (Figure 8).

Galena is generally characterized by very low values of trace elements (Se up to $0.05 \mathrm{wt} . \%$ and $\mathrm{Sb}$ $\mathrm{p}$ to $0.02 \mathrm{wt} . \%$ respectively (Table 4 ).

Sphalerite has very low Fe content (up to $1.0 \mathrm{wt} . \%$ ) and is generally devoid of any trace elements (Table 4).

Table 3. EPMA data of molybdenite from porphyry-style mineralization of the Aisymi-Leptokarya prospect.

\begin{tabular}{cccccccccc}
\hline Sample & \multicolumn{3}{c}{ EG16 $(\mathbf{n}=\mathbf{6 4})$} \\
\hline wt. $\%$ & Min & Max & Mean & $\mathbf{1 \sigma}$ & wt. $\%$ & Min & Max & Mean & $\mathbf{1 \sigma}$ \\
\hline Mo & 58.8 & 60.8 & 59.9 & 0.34 & Mo & 58.6 & 60.3 & 59.8 & 0.39 \\
W & bdl & 0.08 & 0.01 & 0.02 & W & bdl & 0.07 & 0.01 & 0.02 \\
Re & bdl & 0.14 & 0.02 & 0.03 & Re & bdl & 0.31 & 0.08 & 0.07 \\
Sn & bdl & 0.02 & 0.002 & 0.01 & Sn & bdl & 0.01 & 0.000 & 0.001 \\
Se & bdl & 0.04 & 0.004 & 0.01 & Se & bdl & 0.03 & 0.003 & 0.01 \\
S & 39.6 & 40.9 & 40.2 & 0.29 & S & 39.6 & 40.8 & 40.1 & 0.34 \\
Total & 99.1 & 100.5 & 100.2 & 0.30 & Total & 99.4 & 100.4 & 100.1 & 0.27 \\
\hline apfu & & & & & 3 & & & & \\
& Min & Max & Mean & $\mathbf{1 \sigma}$ & & Min & Max & Mean & $\mathbf{1 \sigma}$ \\
\hline Mo & 0.982 & 1.018 & 0.996 & 0.007 & Mo & 0.973 & 1.010 & 0.997 & 0.009 \\
W & - & 0.001 & - & - & W & - & 0.001 & 0.000 & 0.000 \\
Re & - & 0.001 & - & - & Re & - & 0.003 & 0.001 & 0.001 \\
Sn & - & - & - & - & Sn & - & - & - & - \\
Se & - & 0.001 & - & - & Se & - & 0.001 & - & - \\
S & 1.98 & 2.02 & 2.00 & 0.007 & S & 1.988 & 2.027 & 2.002 & 0.009 \\
\hline
\end{tabular}


Table 4. EPMA data of galena and sphalerite from base metals veins of the Aisymi-Leptokarya prospect.

\begin{tabular}{cccccccccc}
\hline Sample EG1 & \multicolumn{4}{c}{ Galena $(\mathbf{n}=\mathbf{8})$} & \multicolumn{5}{c}{ Sphalerite $(\mathbf{n}=\mathbf{1 2})$} \\
\hline wt.\% & Min & Max & Mean & $\mathbf{1 \sigma}$ & wt. $\%$ & Min & Max & Mean & $\mathbf{1 \sigma}$ \\
\hline $\mathrm{Pb}$ & 86.6 & 87.1 & 86.8 & 0.19 & $\mathrm{Fe}$ & 0.51 & 1.00 & 0.79 & 0.16 \\
$\mathrm{Se}$ & 0.01 & 0.02 & 0.01 & 0.004 & $\mathrm{Zn}$ & 65.4 & 67.2 & 66.3 & 0.54 \\
$\mathrm{Sb}$ & 0.02 & 0.05 & 0.03 & 0.01 & $\mathrm{~S}$ & 32.5 & 33.3 & 32.9 & 0.24 \\
$\mathrm{~S}$ & 13.2 & 13.6 & 13.4 & 0.14 & Total & 99.5 & 100.5 & 100.1 & 0.37 \\
Total & 100.0 & 100.5 & 100.3 & 0.175 & & & & & \\
\hline apfu & & & & & $\mathbf{2}$ & & & & \\
\hline & Min & Max & Mean & $\mathbf{1 \sigma}$ & & Min & Max & Mean & $\mathbf{1 \sigma}$ \\
$\mathrm{Pb}$ & 0.993 & 1.008 & 1.001 & 0.006 & Fe & 0.009 & 0.017 & 0.013 & 0.003 \\
$\mathrm{Se}$ & 0.000 & 0.000 & 0.000 & 0.000 & $\mathrm{Zn}$ & 0.973 & 1.000 & 0.986 & 0.008 \\
$\mathrm{Sb}$ & 0.000 & 0.001 & 0.000 & 0.000 & $\mathrm{~S}$ & 0.988 & 1.010 & 1.000 & 0.006 \\
$\mathrm{~S}$ & 0.991 & 1.007 & 0.998 & 0.006 & & & & & \\
\hline
\end{tabular}

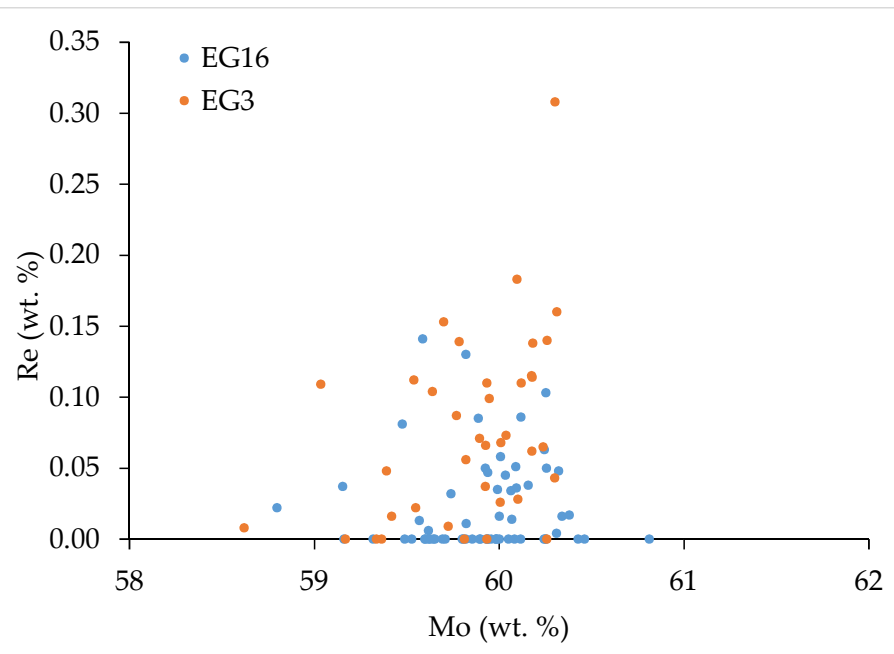

Figure 7. Mo vs Re plot of analysed molybdenites from the porphyry-style mineralization of the Aisymi-Leptokarya prospect.
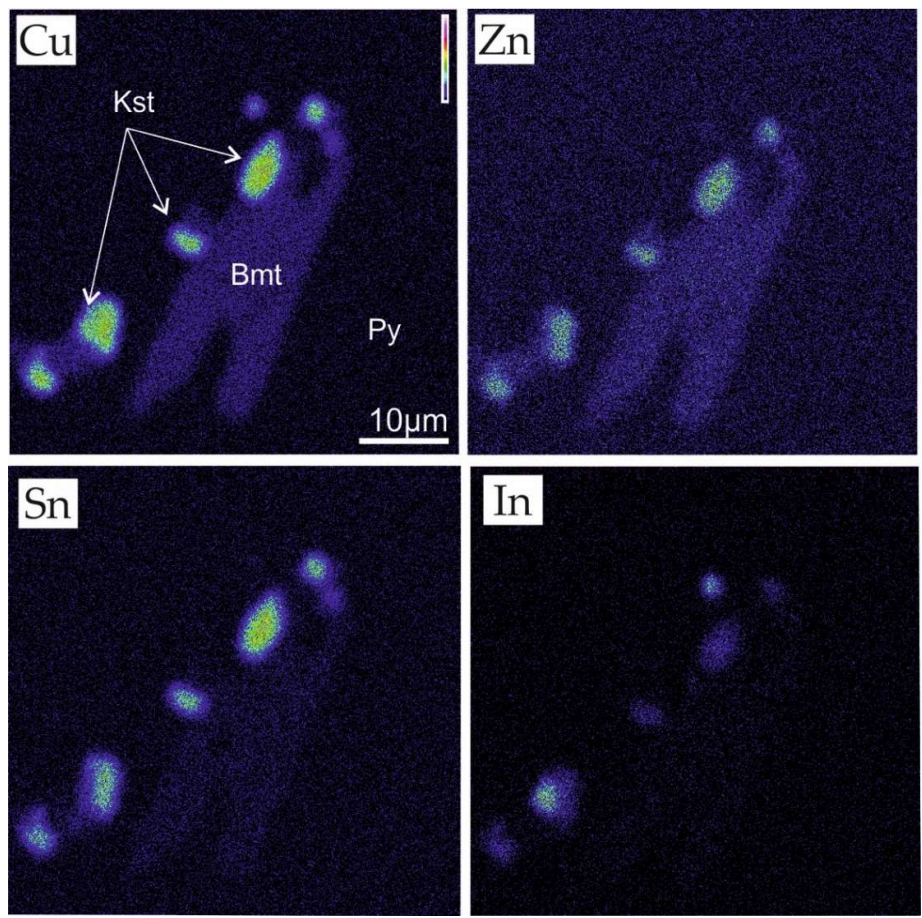

Figure 8. X-ray element mapping demonstrating distribution of $\mathrm{Cu}, \mathrm{Zn}, \mathrm{Sn}$ and $\mathrm{In}$ in the kesterite crystal shown in Figure 6b. 


\subsection{Bulk Ore Geochemistry}

The Aisymi-Leptokarya prospect has not yet been drilled or has been the subject of exploration utilizing modern techniques. Preliminary bulk ore analyses of surface samples from the porphyry-style veins revealed a significant enrichment in Mo, with values up to $215 \mathrm{ppm}$ (Table 5), with a mean of $110 \mathrm{ppm}$. It must be noted that elevated Mo concentrations lacks correlation with any other element such as $\mathrm{Cu}$ or $\mathrm{Au}$, which characterizes mineralization elsewhere in the nearby area [15]. Selenium is also enriched, up to $29 \mathrm{ppm}$, whereas Bi and Sn display relatively elevated concentrations (up to 8 and $14 \mathrm{ppm}$, respectively). Gold and Ag content is rather insignificant.

The base metal veins are characterized by enrichment in Bi and Sn, with values up to 16 and $17 \mathrm{ppm}$, respectively. Mo displays elevated concentration as well (up to $20 \mathrm{ppm}$ ). Au and Ag values reach up to $24 \mathrm{ppb}$ and $9 \mathrm{ppm}$ respectively.

Table 5. Selected bulk-ore trace elements analyses (acquired by ICP-MS) from porphyry-style and base metals veins from the Aisymi-Leptokarya prospect. Concentrations are in ppm, except for gold in ppb.

\begin{tabular}{cccccccccccc}
\hline Sample & EG2 & EG3 & EG6 & EG14 & EG16b & EG27 & EG29 & EG31 & EG1 & EG11 & EG25 \\
\hline \multicolumn{7}{c}{ Porphyry-Style Veins } \\
\hline $\mathrm{Au}$ & 4.1 & 0.8 & 5.3 & 5.9 & 1.1 & 1.3 & 7.9 & 7.1 & $<0.5$ & 4.6 & 23.5 \\
$\mathrm{Ag}$ & 1.2 & 0.5 & 0.9 & 0.2 & $<0.1$ & 0.7 & 1 & 1.3 & 3.9 & 8.6 & 7.9 \\
$\mathrm{Mo}$ & 38.6 & 182 & 114 & 65.3 & 150 & 215 & 96.3 & 20.3 & 20.2 & 0.5 & 1.2 \\
$\mathrm{Se}$ & 1 & 29 & 2.2 & 0.8 & $<0.5$ & 0.5 & $<0.5$ & $<0.5$ & 4.6 & 4.5 & $<0.5$ \\
$\mathrm{Te}$ & $<1$ & $<1$ & $<1$ & $<1$ & $<1$ & $<1$ & $<1$ & $<1$ & 3 & $<1$ & 3 \\
$\mathrm{Bi}$ & 2.3 & 1.4 & 8.2 & 4.8 & 0.7 & 0.8 & 1.1 & 0.8 & 3.4 & 16.4 & 0.8 \\
$\mathrm{Sn}$ & 6 & 13 & 5 & 13 & 2 & 3 & 14 & 2 & 6 & 17 & 1 \\
$\mathrm{Sb}$ & 1.7 & 1.2 & 1.4 & 0.4 & 0.3 & 0.1 & 1.1 & 10.6 & 6.1 & 0.3 & 9.8 \\
$\mathrm{~Pb}$ & 94.5 & 16.6 & 28.7 & 18.4 & 8.7 & 10.8 & 31.5 & 25.1 & $>10,000$ & 5258 & 996 \\
$\mathrm{Zn}$ & 58 & 10 & 4 & 38 & 6 & 9 & 2 & 10 & $>10,000$ & 789 & 71 \\
$\mathrm{Cu}$ & 9.8 & 3.2 & 1 & 6.8 & 3.3 & 18.3 & 2 & 49.2 & 277 & 379 & 23.5 \\
$\mathrm{As}$ & 1.6 & $<0.5$ & 18.7 & 45.6 & 2.7 & 6.2 & 20 & 24.8 & 13.7 & 40.4 & 31.1 \\
\hline
\end{tabular}

\subsection{Genetic Implications}

This study demonstrates a new porphyry-style prospect in the Kassiteres-Leptokarya magmatic suite, located in the Aisymi-Leptokarya area. The studied mineralization is hosted in an Oligocene felsic dike complex, which intrudes into upper Eocene volcanoclastic sediments and the Leptokarya pluton. The felsic dike complex displays a rhyodacitic to dacitic composition with post-collisional geochemical signature. Mineralization is composed by porphyry-style quartz stockwork in the felsic dike complex and is associated with potassic alteration, dominated by K-feldspar, which grades outwards into propylitic assemblages. Early alteration and mineralization are overprinted by D-type veins and late-stage, base metal veins associated with quartz-sericite \pm carbonate alteration assemblages. Ore minerals within the porphyry stockworks consist mainly of pyrite, molybdenite, kesterite, bismuthinite and galena. Late base-metal veins are dominated by sphalerite, galena, chalcopyrite and tennantite.

The absence of drilling data and the altered nature of the analysed samples, make it difficult to classify the studied mineralization. Preliminary bulk ore analyses showed that the Aisymi-Leptokarya porphyry deposit is characterized by an enrichment in Mo, which lacks correlation with any other commodities (e.g., $\mathrm{Cu}, \mathrm{Au}$ ), thus it should be possibly considered as a porphyry-Mo prospect.

The magmatic rocks hosting the Aisymi-Leptokarya porphyry Mo deposit were emplaced in a back-arc geotectonic regime according to Menant et al. [36].

A post-subduction tectonic environment of porphyry formation has been recognized for porphyry deposits worldwide [37] and has implications for some porphyry molybdenum deposits such as the 27 Ma old Quartz Hill, Alaska (USA) [38], the 33 Ma old Mačkatica (Serbia) [39], the 18 Ma old Pinarbaşi (Turkey) [40], the 4 Ma old Malala (Indonesia) [41] and the Shapinggou and Tianmugou, China, which were formed in a post collisional tectonic setting [42]. 
These post-subduction porphyry Mo deposits, as well as the studied Aisymi-Leptokarya porphyry Mo deposit, share common features with the arc-related, or Endako-type and the collision to post-collision-related, or Dabie Shan, porphyry Mo deposits, as for example the low $\mathrm{Nb}$ and $\mathrm{Rb}$ contents in the causative intrusion [43]. Despite its post-subduction geochemical affinities, it cannot be classified as Climax-type porphyry Mo deposit, since the hosting intrusives display no features of anorogenic magmatism.

The Re anomalies in the analysed molybdenite are in accordance with the observations of Voudouris et al. [15], who reported moderate to extremely-high Re content in molybdenites from a number of porphyry-type deposits in Greece.

The enrichment of $\mathrm{Bi}, \mathrm{Pb}$ and $\mathrm{Zn}$ in the polymetallic veins in the studied prospect is also a common feature of many porphyry Mo deposits worldwide [38]. Furthermore, these deposits are known to be enriched in elements like $\mathrm{Sn}, \mathrm{Bi}, \mathrm{Zn}, \mathrm{Pb}$ and $\mathrm{Ag}[38,44]$. This is consistent with the presence of kesterite, bismuthinite, sphalerite and galena in the studied prospect.

Aplitic textures in the microgranite porphyry, which include micrographic and spherulitic quartz-feldspar intergrowths, are common in many porphyry Mo deposits [38,45]. According to Taylor et al. [38] the formation of aplitic texture is regarded as a quenching feature because of rapid ascent and loss of volatiles from the magma due to rapid crystallization of the viscous melt. Candela [45] considered textural variants like those present at Aisymi-Leptokarya microgranite (i.e., porphyritic, aplitic, micrographic and dendritic, acicular and/or skeletal crystals) to be indicative of undercooling, volatile exsolution and ore formation.

Recently, Perkins et al. [28], extending previous studies of Del Moro et al. [24], classified the magmatic rocks of the Maronia-Leptokarya corridor, into two, temporally and geochemically distinct, magmatic complexes, the Kassiteres-Leptokarya magmatic suite and the Maronia plutonic complex respectively. Both complexes comprise magmatic rocks with calc-alkaline to shoshonitic compositions and post-collisional affinities. Porphyry-style $\mathrm{Cu}-\mathrm{Mo}-\mathrm{Au}-\mathrm{Re}$ mineralization, has been recognized in both magmatic complexes and has been attributed to three mineralizing events $[15,16]$. These events are related to granodiorite- and microdiorite porphyries in the Kassiteres-Leptokarya complex (e.g., the Pagoni Rachi and Konos Hill porphyry-epithermal deposits) and to granite porphyry in the Maronia complex.

The igneous rock hosting the studied mineralization is a microgranite porphyry, similar in composition to that hosting the Maronia porphyry Cu-Mo deposit. However, the studied porphyry event lacks any enrichment in $\mathrm{Au}, \mathrm{Cu}$ and Re.

Further field and laboratory work aims to establish the mechanism for elemental enrichment in the studied mineralization, by testing the hypothesis of vapor versus fluid transportation as has been observed in both active volcanoes (e.g., Etna, Italy, Lewotolo and Merapi, Indonesia, Kudryavy, Russia) and magmatic-hydrothermal systems (porphyry and epithermal systems) [46-52].

\section{Conclusions}

The newly-described porphyry Mo prospect in the Aisymi-Leptokarya area, is hosted within a hydrothermally-altered microgranite porphyry and to a lesser extent in the Leptokarya monzodiorite, emplaced in a back-arc geotectonic regime. Hydrothermal alteration includes potassic rimmed by propylitic, overprinted by silicic/sericitic assemblages. Mineralization is found in the form of quartz stockwork veins as well as disseminations in the host rocks. It comprises pyrite, molybdenite, kesterite, bismuthinite and galena. Base metal veins overprint and occur peripherally to the porphyry style mineralization and are associated with sericitic alteration. Bulk ore analyses from porphyry-style mineralized samples yielded very high Mo values. Se, Bi, Sn are also enriched, while the base metal veins are characterized by enrichment in $\mathrm{Bi}$, $\mathrm{Sn}$ and $\mathrm{Ag}$.

The studied mineralization shares similarities to other porphyry Mo deposits emplaced in post-subduction settings elsewhere. 
Author Contributions: E.G. assisted by P.V. and C.M mapped the study area and collected the samples. E.G. and F.Z. obtained the mineralogical and geochemical data which were evaluated by P.S., V.M., C.H. and D.A. Finally, E.G., P.V. and C.M. wrote the manuscript. This paper is part of first author's PhD project.

Funding: This research was partially funded by the University of British Columbia, Mineral Deposit Research Unit under the Western Tethyan Metallogeny Project.

Acknowledgments: First author would like to thank George Economou, Institute of Geology and Mineral Exploration, Greece for his assistance in laboratory work. Two anonymous reviewers and the Associate Editor Marco Viccaro are kindly thanked for providing constructive comments that highly improved the manuscript.

Conflicts of Interest: The authors declare no conflict of interest.

\section{References}

1. Zeng, Q.D.; Liu, J.M.; Qin, K.Z.; Fan, H.R.; Chu, S.X.; Wang, Y.B.; Zhou, L.L. Types, characteristics, and time-space distribution of molybdenum deposits in China. Int. Geol. Rev. 2013, 55, 1311-1358. [CrossRef]

2. Chen, Y.J.; Zhang, C.; Wang, P.; Pirajno, F.; Li, N. The Mo deposits of Northeast China: A powerful indicator of tectonic settings and associated evolutionary trends. Ore Geol. Rev. 2017, 81, 602-640. [CrossRef]

3. Singer, D.A.; Berger, V.I.; Moring, B.C. Porphyry Copper Deposits of the World: Database, Map and Preliminary Analysis; USGS Open-File Report; The United States Geological Survey: Reston, WV, USA, 2002.

4. Chen, Y.J.; Santosh, M.; Somreville, I.D.; Chen, H.Y. Indosinian tectonics and mineral systems in China: An introduction. Geol. J. 2014, 49, 331-337. [CrossRef]

5. Selby, D.; Nesbitt, B.E.; Muehlenbachs, K.; Prochaska, W. Hydrothermal alteration and fluid chemistry of the Endako porphyry molybdenite deposit, British Columbia. Econ. Geol. 2000, 95, 183-202. [CrossRef]

6. Wallace, S.R. SEG presidential address: The climax-type molybdenite deposits: What they are, where they are, and why they are. Econ. Geol. 1995, 90, 1359-1380.

7. Mi, M.; Chen, Y.J.; Yang, Y.F.; Wang, P.; Li, F.L.; Wan, S.Q.; Xu, Y.L. Geochronology and geochemistry of the giant Qian'echong Mo deposit, Dabie Shan, eastern China: Implications for ore genesis and tectonic setting. Gondwana Res. 2015, 27, 1217-1235. [CrossRef]

8. Hu, S.X. Petrology of Metasomatic Rocks and Implications for Ore Exploration; Science Press: Beijing, China, 2002; Volume 264. (In Chinese)

9. Khashgerel, B.E.; Rye, R.O.; Hedenquist, J.W.; Kavalieris, I. Geology and reconnaissance stable isotope study of the Oyu Tolgoi porphyry Cu-Au system, South Gobi, Mongolia. Econ. Geol. 2006, 101, 503-522. [CrossRef]

10. Chen, Y.J.; Ni, P.; Fan, H.R.; Pirajno, F.; Lai, Y.; Su, W.C.; Zhang, H. Diagnostic fluid inclusions of different types hydrothermal gold deposits. Acta Petrol. Sin. 2007, 23, 2085-2108, (In Chinese with English abstract).

11. Arikas, K.; Voudouris, P. Hydrothermal alterations and mineralizations of magmatic rocks in the southeastern Rhodope massif. Acta Vulcanol. 1998, 10, 353-365.

12. Melfos, V.; Vavelidis, M.; Christofides, G.; Seidel, E. Origin and evolution of the Tertiary Maronia porphyry copper-molybdenum deposit, Thrace, Greece. Mineral. Depos. 2002, 37, 648-668. [CrossRef]

13. Melfos, V.; Voudouris, P. Cenozoic metallogeny of Greece and potential for precious, critical and rare metals exploration. Ore Geol. Rev. 2017, 59, 1030-1057. [CrossRef]

14. Voudouris, P.; Melfos, V.; Spry, P.G.; Kartal, T.; Schleicher, H.; Moritz, R.; Ortelli, M. The Pagoni Rachi/Kirki $\mathrm{Cu}-\mathrm{Mo}-\mathrm{Re}-\mathrm{Au}-\mathrm{Ag}$-Te deposit, northern Greece: Mineralogical and fluid inclusion constraints on the evolution of a telescoped porphyry-epithermal system. Can. Mineral. 2013, 51, 411-442. [CrossRef]

15. Voudouris, P.; Melfos, V.; Spry, P.G.; Bindi, L.; Moritz, R.; Ortelli, M.; Kartal, T. Extremely Re-rich molybdenite from porphyry Cu-Mo-Au prospects in northeastern Greece: Mode of occurrence, causes of enrichment, and implications for gold exploration. Minerals 2013, 3, 165-191. [CrossRef]

16. Mavrogonatos, C.; Voudouris, P.; Spry, P.G.; Melfos, V.; Klemme, S.; Berndt, J.; Baker, T.; Moritz, R.; Bissig, T.; Monecke, T.; Zaccarini, F. Mineralogical Study of the Advanced Argillic Alteration Zone at the Konos Hill Mo-Cu-Re-Au Porphyry Prospect, NE Greece. Minerals 2018, 8, 479. [CrossRef]

17. Galanopoulos, E.; Voudouris, P.; Mavrogonatos, K.; Melfos, V. A New Porphyry Mo Mineralization at Aisymi-Leptokarya, Southeastern Rhodope, NE Greece: Mineralogical and Geochemical Constraints. In Proceedings of the 8. Geochemistry Symposium, Antalya, Turkey, 2-6 May 2018. 
18. Bonev, N.; Spikings, R.; Moritz, R.; Marchev, P.; Collings, D. 40Ar/39Ar age constraints on the timing of Tertiary crustal extension and its temporal relation to ore-forming and magmatic processes in the Eastern Rhodope Massif, Bulgaria. Lithos 2013, 180-181, 256-270. [CrossRef]

19. Kilias, A.; Falalakis, G.; Sfeikos, A.; Papadimitriou, E.; Vamvaka, A.; Gkarlaouni, C. The Thrace basin in the Rhodope province of NE Greece-A tertiary supradetachment basin and its geodynamic implications. Tectonophysics 2013, 90, 595-596. [CrossRef]

20. Mposkos, E.; Baziotis, I.; Leontakianakos, G.; Harry, P.H. The metamorphic evolution of the high-pressure Kechros complex in East Rhodope (NE Greece): Implications from Na-Al-rich leucocratic rocks within antigorite serpentinites. Lithos 2013, 177, 17-33. [CrossRef]

21. Papadopoulos, P.; Arvanitides, N.D.; Zanas, I. Some preliminary geological aspects on the Makri unit (phyllite series); peri-Rhodopian zone. Geol. Rhod. 1989, 1, 34-42.

22. Maratos, G.; Andronopoulos, B. Nouvelles données sur l'age desphyllites du Rhodope. Bull. Geol.Soc. Greece 1964, 6, 113-132.

23. Innocenti, F.; Kolios, N.; Manetti, O.; Mazzuoli, R.; Peccerillo, G.; Rita, F.; Villari, L. Evolution and geodynamic significance of the Tertiary orogenic volcanism in northeastern Greece. Bull. Volcanol. 1984, 47, 25-37. [CrossRef]

24. Del Moro, A.; Innocenti, F.; Kyriakopoulos, C.; Manetti, P.; Papadopoulos, P. Tertiary granitoids from Thrace (Northern Greece): Sr isotopic and petrochemical data. N. Jb. Min. Abh. 1988, 159, 113-135.

25. Eleftheriadis, G.; Christofides, G.; Papadopoulos, P. Petrology and geochemistry of Leptokarya-Kirki plutonic intrusions in the NE Rhodope Massif, Thrace, Greece. Geol. Rhod. 1989, 280-289.

26. Alfieris, D.; Arvanitidis, N.; Katirtzoglou, K. Petrology and geochemistry of acid dyke-rocks in the east Rhodope (Essimi) area. Geol. Rhod. 1989, 1, 268-279.

27. Mavroudchiev, B.; Nedyalkov, R.; Eleftheriadis, G.; Soldatos, T.; Christofides, G. Tertiary plutonic rocks from East Rhodope in Bulgaria and Greece. Bull. Geol. Soc. Greece 1993, 28, 643-660.

28. Perkins, R.; Cooper, F.; Condon, D.; Tattitch, B.; Naden, J. Post-collisional Cenozoic extension in the northern Aegean: The high-K to shoshonitic intrusive rocks of the Maronia Magmatic Corridor, northeastern Greece. Lithosphere 2018, 10, 582-601. [CrossRef]

29. Winchester, J.A.; Floyd, P.A. Geochemical discrimination of different magma series and their differentiation products using immobile elements. Chem. Geol. 1977, 20, 325-343. [CrossRef]

30. Pearce, J.A.; Harris, N.B.W.; Tindle, A.G. Trace element discrimination diagrams for the tectonic interpretation of granitic rocks. J. Petrol. 1984, 25, 956-983. [CrossRef]

31. Pearce, J.A. Source and settings of granitic rocks. Episodes 1996, 19, 120-125.

32. Boynton, W.V. Cosmochemistry of the rare earth elements: Meteorite studies. In Rare Earth Element Geochemistry; Henderson, P., Ed.; Elsevier Science: Amsterdam, The Netherlands, 1985; Chapter 3.

33. McDonough, W.F.; Sun, S. The composition of the Earth. Chem. Geol. 1995, 120, 223-253. [CrossRef]

34. Christofides, G.; Pecskay, Z.; Soldatos, T.; Eleftheriadis, G.; Koroneos, A. The Tertiary Evros volcanic rocks (Greece): Petrology, K/Ar geochronology and volcanism evolution. Geol. Carpathica 2004, 55, 397-409.

35. Seedorff, E.; Dilles, J.H.; Proffett, J.M.; Einaudi, M.T.; Zurcher, L.; Stavast, W.; Johnson, D.A.; Barton, M.D. Porphyry deposits: Characteristics and origin of hypogene features. Econ. Geol. 2005, 100, 251-298.

36. Menant, A.; Jolivet, L.; Tuduri, J.; Loiselet, C.; Bertrand, G.; Guillou-Frottier, L. 3D subduction dynamics: A first-order parameter of the transition from copper- to gold-rich deposits in the eastern Mediterranean region. Ore Geol. Rev. 2018, 94, 118-135. [CrossRef]

37. Richards, J.P. Postsubduction porphyry $\mathrm{Cu}-\mathrm{Au}$ and epithermal deposits-Products of remelting subduction-modified lithosphere. Geology 2009, 37, 247-250. [CrossRef]

38. Taylor, R.D.; Hammarstrom, J.M.; Piatak, N.M.; Seal, R.R. Arc-Related Porphyry Molybdenum Deposit Model; Scientific Investigations Report 2010-5070-D; The Unated States Geological Survey: Reston, WV, USA, 2012.

39. Simic, M. Metallogenic features of the Mackatica ore field-Bratislava, Slovakia. In Proceedings of the XVII Congress of Carpathian-Balkan Geological Association, Bratislava, Slovakia, 1-4 September 2002; Veda, Publishing House of the Slovak Academy of Sciences: Bratislava, Slovakia, 2002.

40. Delibaş, O.; Moritz, R.; Chiaradia, M.; Selby, D.; Ulianov, A.; Revan, M.K. Post-collisional magmatism and ore-forming systems in the Menderes massif: New constraints from the Miocene porphyry Mo-Cu Pınarbaş1 system, Gediz-Kütahya, western Turkey. Miner. Depos. 2017, 52, 1157-1178. [CrossRef] 
41. Van Leeuwen, T.M.; Taylor, R.; Coote, A.; Longstaffe, F.J. Porphyry molybdenum mineralization in a continental collision setting at Malala, northwest Sulawesi, Indonesia. J. Geochem. Explor. 1994, 50, 279-315. [CrossRef]

42. Chen, Y.-J.; Wang, P.; Li, N.; Yang, Y.-F.; Pirajno, F. The collision-type porphyry Mo deposits in Dabie Shan, China. Ore Geol. Rev. 2017, 81, 405-430. [CrossRef]

43. Westra, G.; Keith, S.B. Classification and genesis of stockwork molybdenum deposits. Econ. Geol. 1981, 76, 844-873. [CrossRef]

44. Sinclair, W.D. Porphyry deposits. In Mineral Deposits of Canada-A Synthesis of Major Deposit-Types, District Metallogeny, the Evolution of Geological Provinces, and Exploration Methods; Special Publication No. 5; Goodfellow, W.D., Ed.; Geological Association of Canada, Mineral Deposits Division: St. John's, NL, Canada, 2007; pp. 223-243.

45. Candela, P.A. A Review of Shallow, Ore-related Granites: Textures, Volatiles, and Ore Metals. J. Petrol. 1997, 38, 1619-1633. [CrossRef]

46. Symonds, R.; Rose, W.; Reed, M.; Lichte, F.; Finnegan, D. Volatilization, transport and sublimation of metallic and non-metallic elements in high temperature gases at Merapi volcano, Indonesia. Geochim. Cosmochim. Acta 1987, 51, 2083-2101. [CrossRef]

47. De Hoog, J.; van Bergen, M. Volatile-induced transport of HFSE, REE, Th and U in arc magmas: Evidence from zirconolite-bearing vesicles in potassic lavas of Lewotolo volcano (Indonesia). Contrib. Miner. Petrol. 2000, 139, 485-502. [CrossRef]

48. Williams-Jones, A.; Heinrich, C. Vapor transport of metals and the formation of magmatic-hydrothermal ore deposits. Econ. Geol. 2005, 100, 1287-1312. [CrossRef]

49. Yudovskaya, M.; Distler, V.; Chaplygin, I.; Mokhov, A.; Trubkin, N.; Gorbacheva, S. Gaseous transport and deposition of gold in magmatic fluid: Evidence from the active Kudryavy volcano, Kurile Islands. Miner. Depos. 2006, 40, 828-848. [CrossRef]

50. Mazziotti-Tagliani, S.; Nicotra, E.; Viccaro, M.; Gianfagna, A. Halogen-dominant mineralization at Mt. Calvario dome (Mt. Etna) as a response of volatile flushing into the magma plumbing system. Mineral. Petrol. 2012, 106, 89-105. [CrossRef]

51. Ferlito, C.; Viccaro, M.; Cristofolini, R. Volatile-rich magma injection into the feeding system during the 2001 eruption of Mt. Etna (Italy): Its role on explosive activity and change in rheology of lavas. Bull. Volcanol. 2009, 71, 1149-1158. [CrossRef]

52. Pokrovski, G.; Borisova, Y.; Bychkov, A. Speciation and transport of metals and metalloids in geological vapors. Rev. Mineral. Geochem. 2013, 76, 165-218. [CrossRef] 